\title{
The Effect of COVID-19 Pandemic on the Philippine Stock Exchange, Peso-Dollar Rate and Retail Price of Diesel
}

\author{
Aileen L. CAMBA', Abraham C. CAMBA Jr. ${ }^{2}$ \\ Received: July 18, 2020 Revised: August 23, 2020 Accepted: September 10, 2020
}

\begin{abstract}
This paper examines the effect of COVID-19 pandemic on the Philippine stock exchange, peso-dollar rate and retail price of diesel using robust least squares regression and vector autoregression (VAR). The robust least squares regression using MM-estimation method concluded that COVID-19 daily infection has negative and statistically significant effect on the Philippine stock exchange index, pesodollar exchange rate and retail pump price of diesel. This is consistent with the results of correlation diagnostics. As for the VAR model, the lag values of the independent variable disclose significance in explaining the Philippine stock exchange index, peso-dollar exchange rate and retail pump price of diesel. Moreover, in the short run, the impulse response function confirmed relative effect of COVID-19 daily infections and the variance decomposition divulge that COVID-19 daily infections have accounted for only minor portion in explaining fluctuations of the Philippine stock exchange index, peso-dollar exchange and retail pump price of diesel. In the long term, the influence levels off. The Granger causality test suggests that COVID-19 daily infections cause changes in the Philippine stock exchange index and peso-dollar exchange rate in the short run. However, COVID-19 infection has no causal link with retail pump price of diesel.
\end{abstract}

Keywords: Coronavirus, COVID-19 Pandemic, Philippine Stock Exchange, Robust Least Squares Regression, VAR Approach

JEL Classification Code: G11, G40, G41, I15, I18

\section{Introduction}

The novel coronavirus or COVID-19, which Chinese authorities first reported to the World Health Organization (WHO) on 31 December 2019, has spread globally. The economic disruptions caused by the outbreak of COVID-19 is hurting economies, regardless of income level. The increased uncertainty is being reflected in lower

${ }^{1}$ First Author and Corresponding Author. Associate Professor IV, Department of Economics, College of Social Sciences and Development, Polytechnic University of the Philippines, Sta. Mesa, Manila, Philippines [Postal Address: P. Tuazon Ave., Bgry. Kaunlaran, Quezon City, Metro Manila, 1111, Philippines]

Email: alcamba@pup.edu.ph

${ }^{2}$ Assistant Professor II, Department of Economics, College of Social Sciences and Development, Polytechnic University of the Philippines, Sta. Mesa, Manila, Philippines.

Email: accamba@pup.edu.ph_.

(c) Copyright: The Author(s)

This is an Open Access article distributed under the terms of the Creative Commons Attribution Non-Commercial License (https://creativecommons.org/licenses/by-nc/4.0/) which permits unrestricted non-commercial use, distribution, and reproduction in any medium, provided the original work is properly cited. valuations and increased volatility in the financial markets affecting business investment, household consumption, and international trade (Boon et al., 2020; Wren-Lewis, 2020; Ramelli \& Wagner, 2020). The Philippines, on January 30, 2020, confirmed its first case of novel coronavirus. Since then the virus has infected more than 36,000 Filipinos (as of 30 June 2020), although more than 1,200 individuals have recovered. The rapid rise in domestic infections is disrupting the country's economic activities and value chains reducing demand nationwide. Moreover, the spread of COVID-19 to the provinces is expected to have a much larger impact on the Philippine economy.

The uncertainty about the spread of the virus and the level of aggregate demand could hurt the country's stock market, bring more volatility in the exchange rate, and could further depress oil prices. This study examines the effect of the number of COVID-19 daily infections on the Philippine stock exchange, peso-dollar rate and retail price of diesel using robust least squares regression and vector autoregression (VAR) approach. 


\section{Literature Review}

\subsection{COVID-19 Impact on Stock Markets}

Wren-Lewis (2020) claims that the COVID-19 pandemic would significantly affect the GDP of countries because of reductions in production and consumer demands. Moreover, if banks fail to meet the financial needs of firms due to falling demand, this will ultimately lead to the collapse of the stock markets worldwide. Boon et al. (2020) describes three channels through which the COVID-19 pandemic may affect the global economy: 1) closure of factories, cutbacks in the service sector, disruption in the worldwide supply chain will lead to an overall decline in the supply; 2) significant drop in travel and tourism, education and other entertainment services will affect the demand side; 3 ) increases in uncertainty will lead to a rise in the opportunity cost of investment. Ramelli and Wagner (2020) examines the market reactions to the 2019 novel coronavirus disease (COVID-19) providing new insights into how real shocks and financial policies drive firm value. Thus, internationallyoriented firms, especially those more exposed to trade with China, underperformed. As the virus spread to Europe and the United States, corporate debt and cash holdings emerged as important value drivers. Overall, the results illustrate how anticipated real effects from the health crisis, a rare disaster, were amplified through financial channels.

Gormsen and Koijen (2020) shows that news about fiscal stimulus boosts the stock market and long-term growth, but did little to increase short-term growth expectations. Ozili and Arun (2020) found that restriction on internal movement and higher fiscal policy spending had a positive impact on the level of economic activities, although the increasing number of confirmed coronavirus cases did not have a significant effect on the level of economic activities. Baker et al. (2020) concludes that no previous infectious disease episode led to daily stock-market swings that even remotely resemble the response in the past month to COVID-19 developments.

Yilmazkuday (2020) investigates the effect of the coronavirus disease 2019 (COVID-19) cases in the U.S. on the S\&P 500 Index using daily data covering the period between December 31, 2019, and May 1, 2020. Using a structural vector autoregression model, results suggest that having 1-percent increase in cumulative daily COVID-19 cases in the U.S. results in about 0.01 percent of a cumulative reduction in the S\&P 500 Index after one day and about 0.03 percent reduction after one month. Historical decomposition of the S\&P 500 Index further suggests that the negative effect of COVID-19 cases in the U.S. on the S\&P 500 Index have been mostly observed during March 2020. Alam et al. (2020) investigates the impact COVID-19 to the stock market of India from February 24 to April 17, 2020. The results confirm that the market reacted positively with significantly positive Average Abnormal Returns (AAR) during the lockdown period. Since investors anticipated the lockdown, they reacted positively, however, in the pre-lockdown period investors panicked with negative AAR. Khan et al. (2020) investigates the impact of COVID-19 pandemic on the stock markets of 16 countries using pooled OLS regression, conventional t-test and Mann-Whitney test. Pooled OLS estimation result shows that the growth rate of weekly new cases of COVID-19 negatively predicts the return in stock markets. Using a t-test and Mann-Whitney test reveal that investors in these countries do not react to the media news of COVID-19 at the early stage of the pandemic. However, after human-to-human transmission has been confirmed, stock market indices negatively reacted to the news in both short- and long- event window.

\subsection{COVID-19 Impact on Exchange Rates}

The FRED Blog (2020) showed that COVID-19 pandemic has affected major economies' exchange rates. In particular, Canada's and the United Kingdom's exchange rates spiked at the beginning of March 2020, but they seem to have recovered by the end of March. The euro seems to be unaffected by the global pandemic, compared with the U.S. dollar. Despite the coronavirus origin, China's exchange rate remained constant.

Corsetti and Marin (2020) concludes that the spread of COVID-19 has led to large foreign exchange movements. In particular, the pattern of foreign exchange dynamics is fast-tracked and capital outflows from emerging markets, week on week, are much larger compared to the previous 2007-2008 financial crisis. In ASEAN, Hayat and Mechelen (2020) sees currencies to weaken substantially in the short term primarily due to COVID-19 pandemic. The uncertainties triggered a swift outflow of capital, causing rapid depreciation of the exchange rates across the region (ASEAN Policy Brief, 2020). That is, key currencies in the region considerably depreciated, specifically the Thai Baht, Indonesian Rupiah, and Singapore Dollar. The largest depreciation was seen in the Indonesian Rupiah (IDR) at 19.8 percent, from IDR13,662 per USD in end-January to IDR16,367 in end-March.

Collins and Gagnon (2020) suggests that the most important policies to help economies from unwelcome depreciations caused by COVID-19 pandemic includes providing access to central bank swap lines, beefing up lending capacity at the international financial institutions and keeping markets open for exports. Reserve-currency countries may wish to consider coordinating direct foreign exchange intervention with affected countries if these unwelcome exchange rate tensions persist. Blanchard et al. (2015) provided considerable evidence that sterilized foreign exchange intervention does have significant effects 
on exchange rates, especially in countries with restrictions on cross-border capital mobility. Modest interventions between currencies of advanced economies with open and sophisticated financial markets might have only minor effects, evidence suggests that official purchases of currencies of emerging-market and developing economies often have more substantial effects.

\subsection{COVID-19 Impact on Oil Prices}

Pandemics such as COVID-19 can affect multiple supply chains simultaneously and cover multiple regions globally. Hence, these effects last longer, they can be more unpredictable, and they can result in simultaneous disruptions in supply, demand, and logistics infrastructure. For example, according to Ivanov (2020), 94 percent of the Fortune 1000 companies have experienced supply chain disruptions due to COVID-19. Similarly, Araz et al. (2020) underline that COVID-19 has broken many global supply chains simultaneously. Although these effects are not unique to COVID-19, and they were also observed in earlier epidemic outbreaks works of Chou et al. (2004) and Calnan et al. (2018).

Consistent with prior studies, Baldwin and Tomiura (2020) predicted that COVID-19 is both a supply and a demand shock that will result in reductions in both imports and exports. These predictions are reflected in the paper of Yilmazkuday (2020) who investigated the COVID-19 cases from China and the rest of the world. Results based on a structural vector autoregression suggest that a weekly increase of 1,000 daily COVID-19 cases in China results in about 7 percent of a cumulative reduction in Baltic Exchange Dry Index after three months, whereas a weekly increase of 1,000 daily COVID-19 cases in the rest of the world results in about 0.4 percent of a cumulative reduction in crude oil prices. The historical decomposition results further suggest that the oil price plunge starting from March 2020 is mostly explained by the corresponding OPEC disagreement. Arezki and Nguyen (2020) identified that negative supply and demand shocks have impacted oil prices. The demand component of the oil shock is linked to the sharp reduction in oil consumption stemming from precautionary measures to stop the spread of the COVID-19. This includes lockdowns, which have brought economies around the world to a standstill. In addition to the shock from COVID-19, the breakdown in negotiations between OPEC and its allies led to what will likely be a persistent collapse in oil prices. On 5 March 2020, OPEC proposed a 1.5 million barrel per day $(\mathrm{mb} / \mathrm{d})$ production cut for the second quarter of 2020, of which $1 \mathrm{mb} / \mathrm{d}$ would come from OPEC countries and $0.5 \mathrm{mb} / \mathrm{d}$ from non-OPEC, most prominently Russia. The following day, Russia rejected the proposal, prompting Saudi Arabia (the world's largest oil exporter) to boost production to $12.3 \mathrm{mb} / \mathrm{d}$, its full capacity. Saudi Arabia also announced unprecedented discounts of almost 20 percent in key markets. The result was an immediate drop of more than 30 percent in prices and continuing declines since.

\section{Research Methodology}

\subsection{Robust Least Squares Regression}

The model for estimation takes into account the following functional forms:

$$
\begin{aligned}
& \text { PSEI }=f(C O V I D) \\
& \text { PHUSD }=f(C O V I D) \\
& \text { DIESEL }=f(\text { COVID })
\end{aligned}
$$

where: PSEI is the Philippine stock exchange daily adjusted closing index, PHUSD is the Philippine peso-US dollar daily closing exchange rate, DIESEL is the average retail pump price of diesel, and COVID the number of COVID-19 daily infections.

For the convenience of parameter estimation, all variables have undergone logarithmic transformation: LOG(PSEI), LOG(PHUSD), LOG(DIESEL and LOG(COVID). Monthly data from January 31 to June 30, 2020, were sourced online from the websites of World Health Organization (WHO), Yahoo Finance, Bangko Sentral ng Pilipinas (BSP) and the Philippine Department of Energy (DOE).

Before estimating the robust least squares regression, it will be useful to established first the association of the variables using correlation analysis. That is, coefficient of correlation was utilized to examine the degree of association of the number of COVID-19 daily infections on the Philippine stock exchange index, Philippine peso-US dollar exchange rate and average retail pump price of diesel. The method of robust least squares regression is designed to be robust, or less sensitive, to outliers. In this study we applied the method of MM-estimation (Yohai, 1987) to address any outliers in both the dependent (LOG(PSEI), LOG(PHUSD), LOG(DIESEL)) and independent (LOG(COVID)) variables. Thus, the regression models of interest are:

$$
\begin{aligned}
& \text { LOG }(\text { PSEI })_{t}=\alpha_{0}+\alpha_{1} \operatorname{LOG}(\text { COVID })_{t}+\varepsilon_{t} \\
& \text { LOG }(\text { PHUSD })_{t}=\alpha_{0}+\alpha_{1} \operatorname{LOG}(\text { COVID })_{t}+\varepsilon_{t} \\
& \text { LOG }(\text { DIESEL })_{t}=\alpha_{0}+\alpha_{1} \operatorname{LOG}(\text { COVID })_{t}+\varepsilon_{t}
\end{aligned}
$$

where: $\alpha_{0}$ and $\alpha_{1}$ are parameter estimates, $\varepsilon$ the error term and $t$ represents time trend. 


\subsection{Vector Autoregression Model}

The vector autoregression (VAR) is used for forecasting systems of interrelated time series and for analyzing the dynamic impact of random disturbances on the system of variables (D(LOG(COVID)) D(LOG(PSEI)) D(LOG(PHUSD)) D(LOG(DIESEL)). The reduced form VAR approach sidesteps the need for structural modeling by treating every endogenous variable in the system as a function of $p$-lagged values of all of the endogenous variables in the system (Christiano, 2012; Lütkepohl \& Krätzig, 2004; Stock \& Watson, 2001; Smith, 1993). The stationary, $k$-dimensional, $\operatorname{VAR}(p)$ process can be written as

$$
y_{t}=A_{1} y_{t-1}+\cdots+A p y_{t-p}+C x_{t}+\varepsilon_{t}
$$

where $y_{t}$ is a $\mathrm{kxl}$ vector of endogenous variables, $x_{t}$ is a dx 1 vector of exogenous variables, $A_{1}, \ldots, A_{p}$ are kxk matrices of lag coefficients to be estimated, $\mathrm{C}$ is kxd matrix of exogenous variable coefficients to be estimated and $\varepsilon_{t}$ is a kx1 white noise innovation process. This paper employs a four-variable VAR system to investigate the causal relations and dynamic interaction of the Philippine stock exchange index (PSEI), the peso-dollar exchange rate (PHUSD) and the retail pump price of diesel (DIESEL) on the number of COVID-19 daily infections in the Philippines.

We then developed impulse response function, variance decomposition and Granger causality Wald test under VAR framework with four endogenous variables. The impulse response function (IRF) in the VAR framework was utilized to trace the effect of a one-time shock to the innovations (i.e., COVID) on current and future values of the endogenous variables. The variance decomposition give proportion of the movements in the dependent variable that are due to their own shocks versus shocks to other variables (Yuliadi, 2020; Brooks, 2019; Campbell, 1991). Variance decompositions are derived from a VAR with orthogonal residuals to facilitate interpretation. Ordering the variables (Cholesky Ordering: $\mathrm{D}(\mathrm{LOG}(\mathrm{COVID})) \quad \mathrm{D}(\mathrm{LOG}(\mathrm{PSEI})) \quad \mathrm{D}$ (LOG(PHUSD)) $\mathrm{D}(\mathrm{LOG}(\mathrm{DIESEL}))$ is important given the causal influence that they have on the dependent variable. The Granger (1969) (Pasquale, 2006) approach to the question of whether $x$ (COVID) causes $y$ (PSEI, PHUSD and DIESEL) is to see how much of the current $y$ can be explained by past values of $y$ and then to see whether adding lagged values of $x$ can improve the explanation. $y$ is said to be Granger-caused by $x$ if $x$ helps in the prediction of $y$, or equivalently if the coefficients on the lagged $x$ 's are statistically significant. In general, it is better to use more rather than fewer lags, since the theory is couched in terms of the relevance of all past information. In this study we picked a lag length of 8 that corresponds to reasonable beliefs about the longest time over which one of the variables could help predict the other. We tested for the absence of Granger causality by estimating the following VAR equations:

$$
\begin{aligned}
& y_{t}=\alpha_{0}+\alpha_{1} y_{t-1}+\cdots+\alpha_{1} y_{t-1}+\beta_{1} x_{t-1}+\cdots+\beta_{l x-l}+\varepsilon_{t} \\
& x_{t}=\alpha_{0}+\alpha_{1} x_{t-1}+\cdots+\alpha_{1} x_{t-1}+\beta_{1} y_{t-1}+\cdots+\beta_{l y-l}+u_{t}
\end{aligned}
$$

for all possible pairs of $(x, y)$ series in the group. The reported F-statistics are the Wald statistics for the joint hypothesis: $\beta_{1}=\beta_{2}=\cdots=\beta_{l}=0$ for each equation. The null hypothesis is that $x$ (COVID) does not Granger-cause $y$ (PSEI, PHUSD and DIESEL) in the first regression and that $y$ does not Granger-cause $x$ in the second regression.

Note that the variables are tested whether they are stationary or not using Augmented Dickey-Fuller (ADF) (Dickey \& Fuller, 1981) and Phillips-Perron (PP) (Phillips \& Perron, 1988).

\section{Results and Discussion}

\subsection{Robust Least Squares Regression Results}

The variables are tested first whether they exhibit some degree of association. Paired correlations $(r)$ were calculated and further supported by the scatter diagrams and box plots in Figure 1. The corresponding correlation patterns indicate some form of negative linear association of the Philippine stock exchange index (PSEI), peso-dollar exchange rate (PHUSD) and retail pump price of diesel (DIESEL) with respect to the number of COVID-19 daily infections (COVID). The correlation coefficients of -0.6215 , -0.5014 and -0.6437 suggests strong negative association of PSEI, PHUSD and DIESEL with COVID, respectively. It is expected that increases in the number of COVID-19 daily infections will lead to decreases in the Philippine stock exchange index, retail pump price of diesel and appreciation of the Philippine peso against the United States dollar.

Table 1 displays the results of the robust least squares regression using MM-estimation method. Turning to the coefficient estimates, we see that the number of COVID-19 daily infections has negative and statistically significant effect on the Philippine stock exchange index, peso-dollar exchange rate and retail pump price of diesel. Since the calculated z-statistic values (in absolute term) of 9.0365, 4.6798 and 15.4535 are all significant at 1 percent level. Thus, a one percent increase in the number of COVID-19 daily infections is associated with a 0.0227 percent and 0.0318 percent decrease in PSEI and DIESEL, respectively. Also, the Philippine peso-US dollar exchange rate will appreciate by 0.0009 percent for every one percent increase in the number of COVID-19 daily infections. Noticed that the estimated coefficients have minimal values, however their negative signs are in accord with the above correlation diagnostics. 

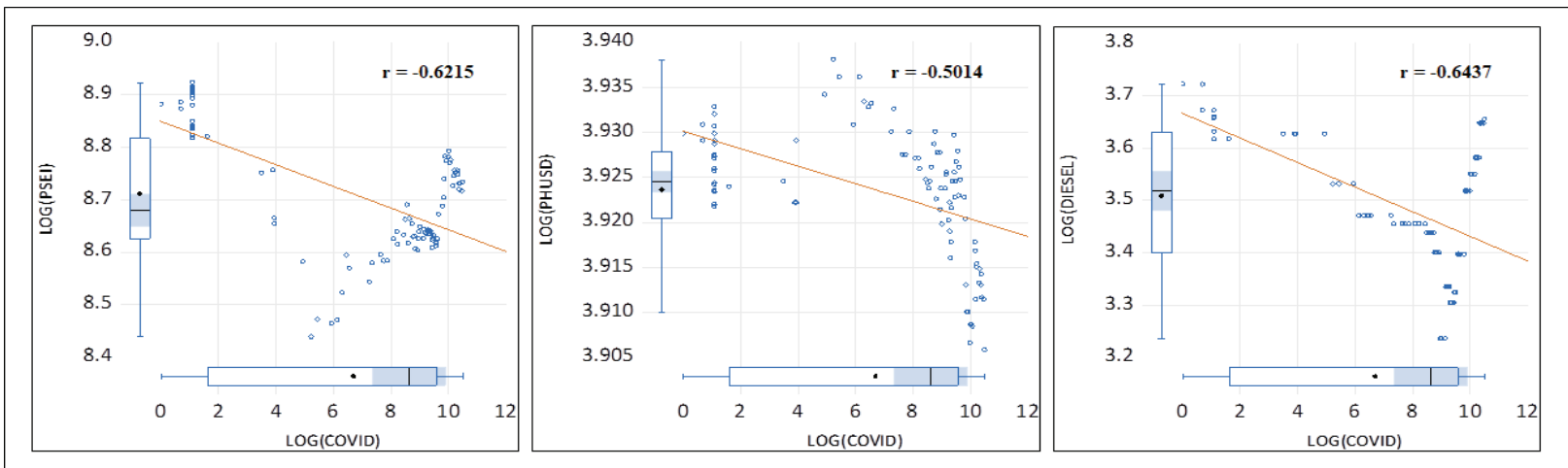

Figure 1: Scatter Diagrams and Box Plots

Table 1: MM-estimation Method

\begin{tabular}{|c|c|c|c|}
\hline & Coefficient & z-Statistic & Probability \\
\hline & \multicolumn{3}{|c|}{ COVID-19 effect on the Philippine Stock Exchange Index } \\
\hline Constant & 8.8760 & 463.4238 & 0.0000 \\
\hline LOG(COVID) & -0.0227 & -9.0365 & 0.0000 \\
\hline \multicolumn{2}{|c|}{ Adjusted $R^{2}=0.3892$} & \multicolumn{2}{|c|}{ Adjusted $R_{w}^{2}=0.5964$} \\
\hline \multicolumn{2}{|l|}{$R_{n}^{2}=81.6587$} & \multicolumn{2}{|c|}{ Prob. $\left(R_{n}^{2}\right.$ statistic $)=0.0000$} \\
\hline & \multicolumn{3}{|c|}{ COVID-19 effect on the Peso-Dollar Exchange Rate } \\
\hline Constant & 3.9296 & 2797.3860 & 0.0000 \\
\hline LOG(COVID) & -0.0009 & -4.6798 & 0.0000 \\
\hline \multicolumn{2}{|c|}{ Adjusted $R^{2}=0.1778$} & \multicolumn{2}{|c|}{ Adjusted $R_{w}^{2}=0.2448$} \\
\hline \multicolumn{2}{|l|}{$R_{n}^{2}=21.9006$} & \multicolumn{2}{|c|}{ Prob. $\left(R_{n}^{2}\right.$ statistic $)=0.0000$} \\
\hline & \multicolumn{3}{|c|}{ COVID-19 effect on the Retail Pump Price of Diesel } \\
\hline Constant & 3.6924 & 235.5324 & 0.0000 \\
\hline LOG(COVID) & -0.0318 & -15.4535 & 0.0000 \\
\hline \multicolumn{2}{|c|}{ Adjusted $R^{2}=0.4128$} & \multicolumn{2}{|c|}{ Adjusted $R_{w}^{2}=0.7862$} \\
\hline \multicolumn{2}{|l|}{$R_{n}^{2}=238.8095$} & \multicolumn{2}{|c|}{ Prob. $\left(R_{n}^{2}\right.$ statistic $)=0.0000$} \\
\hline
\end{tabular}

S settings: tuning $=1.547645$, breakdown $=0.5$, trials $=200$, subsmpl=2, refine $=2$, compare $=5$. $M$ settings: weight $=B$ isquare, tuning $=4.684$ Random number generator: $r n g=k n$, seed $=1314406110$ Huber Type I Standard Errors \& Covariance

The estimated equations also exhibit overall goodness-offit and adjusted measures with $R^{2}$ and $R_{w}^{2}$ ranges from 0.1778 -0.7862 . It means that roughly $17.78-78.62$ percent of the total variation in PSEI, PHUSD and DIESEL is accounted for or explained by the equations fitted on the given data. The $R_{n}^{2}$ statistic values of $81.6587,21.9006$ and 238.8095 with corresponding $p$-value of 0.0000 indicate strong rejection of the null hypothesis that all non-intercept coefficients are equal to zero. This implies that the transformed logarithmic $(\log -\log )$ models are significant. Thus, the number of COVID-19 daily infections has significantly affected the Philippine stock exchange index, peso-dollar exchange rate and retail pump price of diesel for the period January 31June 30, 2020. 
Table 2: ADF and PP Unit Root Test Results

\begin{tabular}{|c|c|c|c|c|c|}
\hline \multirow[b]{2}{*}{ Variable } & \multicolumn{2}{|c|}{ Levels } & \multicolumn{2}{|c|}{ First Difference } & \multirow[b]{2}{*}{$\begin{array}{c}\text { Order of } \\
\text { Integration }\end{array}$} \\
\hline & Intercept & $\begin{array}{c}\text { Intercept, Linear } \\
\text { Trend }\end{array}$ & Intercept & $\begin{array}{l}\text { Intercept, Linear } \\
\text { Trend }\end{array}$ & \\
\hline \multicolumn{6}{|c|}{ Augmented Dickey-Fuller (ADF) } \\
\hline LOG(COVID) & -1.3608 & -0.6036 & $-7.4977^{* * *}$ & $-7.6053^{* * *}$ & $\mathrm{I}(1)$ \\
\hline (LOG(PSEI) & -1.6250 & -1.2730 & $-9.2341^{* * *}$ & $-9.3014^{* * *}$ & $\mathrm{I}(1)$ \\
\hline (LOG(PHUSD) & -1.5057 & -2.7455 & $-10.1884^{* * *}$ & $-10.1832^{* * *}$ & $\mathrm{I}(1)$ \\
\hline (LOG(DIESEL) & -1.4128 & -0.5066 & $-9.6972^{\star * *}$ & $-10.1602^{* * *}$ & $\mathrm{I}(1)$ \\
\hline \multicolumn{6}{|c|}{ Phillips-Perron (PP) } \\
\hline LOG(COVID) & -1.7863 & -0.7306 & $-7.4977^{* * *}$ & $-7.6302^{* * *}$ & $\mathrm{I}(1)$ \\
\hline (LOG(PSEI) & -1.8060 & -1.5319 & $-9.4069^{* * *}$ & $-9.4373^{* * *}$ & $\mathrm{I}(1)$ \\
\hline (LOG(PHUSD) & -1.5054 & -2.8778 & $-10.1964^{* * *}$ & $-10.1836^{* * *}$ & $\mathrm{I}(1)$ \\
\hline (LOG(DIESEL) & -1.4384 & -0.5066 & $-9.6972^{\star \star *}$ & $-10.1596^{* * *}$ & $\mathrm{I}(1)$ \\
\hline
\end{tabular}

Note: ADF test was performed using Schwarz information criterion and the automatic lag selection set at 14. PP test was performed with Bartlett Kernel \& Newey-West Bandwidth. Statistical sig.: ${ }^{* * *}(1 \%),{ }^{* *}(5 \%) \&{ }^{*}(10 \%)$.

Table 3: VAR Lag Order Selection Criteria

\begin{tabular}{|l|c|c|c|c|c|c|}
\hline Lag & LogL & LR & FPE & AIC & SC & HQ \\
\hline 0 & 746.4992 & NA & 0.0000 & -17.0690 & $-16.9556^{*}$ & $-17.0233^{*}$ \\
\hline 1 & 758.2438 & 22.1393 & 0.0000 & -16.9711 & -16.4043 & -16.7429 \\
\hline 2 & 766.7606 & 15.2715 & 0.0000 & -16.7991 & -15.7787 & -16.3882 \\
\hline 3 & 787.3627 & 35.0472 & 0.0000 & -16.9049 & -15.4310 & -16.3114 \\
\hline 4 & 808.4114 & 33.8715 & 0.0000 & -17.0210 & -15.0936 & -16.2449 \\
\hline 5 & 827.3468 & 28.7296 & 0.0000 & -17.0884 & -14.7076 & -16.1297 \\
\hline 6 & 844.6854 & 24.7126 & 0.0000 & -17.1192 & -14.2848 & -15.9779 \\
\hline 7 & 858.4536 & 18.3576 & 0.0000 & -17.0679 & -13.7800 & -15.7440 \\
\hline 8 & 882.6759 & $30.0690^{*}$ & $4.41 e-13^{*}$ & $-17.2569^{*}$ & -13.5155 & -15.7504 \\
\hline 9 & 895.7176 & 14.9905 & 0.0000 & -17.1889 & -12.9940 & -15.4998 \\
\hline 10 & 912.3089 & 17.5448 & 0.0000 & -17.2025 & -12.5541 & -15.3308 \\
\hline
\end{tabular}

\subsection{Vector Autoregression Model Results}

All the variables are stationary at first difference because VAR model needs stationary data to run it as shown in Table 2. The ADF and PP tests of the variables at levels are not stationary as they have unit root. However, the variables are not suffering from unit root when they are at first difference.

In Table 3, lag selection criterion, that is, LR, FPE and AIC suggests to take 8 lags in the VAR model to be optimum lags and employing inverse roots of AR characteristics polynomial indicates that the mod of reciprocal of each characteristic root is inside the circle. That is, the lag order of 8 is appropriate as reflected in Figure 2.
In Table 4, we can see the results of VAR model. Checking what lag of $\mathrm{D}(\mathrm{LOG}(\mathrm{COVID}))$ are significant in explaining $\mathrm{D}(\mathrm{LOG}(\mathrm{PSEI})), \mathrm{D}$ (LOG(PHUSD)) and $\mathrm{D}($ LOG(DIESEL)), we refer to the system equation table. In the system of equation, $\mathrm{D}(\mathrm{LOG}(\mathrm{COVID}))$ lags $2,3,4$, 5,6 and 8 are significant in explaining $\mathrm{D}(\mathrm{LOG}(\mathrm{PSEI}))$ at 5 percent level of significance. When the dependent variable is $\mathrm{D}(\mathrm{LOG}(\mathrm{PHUSD})), \mathrm{D}(\mathrm{LOG}(\mathrm{COVID}))$ lag 4 is significant and when $\mathrm{D}(\mathrm{LOG}(\mathrm{COVID}))$ is the dependent variable, $\mathrm{D}(\mathrm{LOG}(\mathrm{COVID}))$ lag 5 is significant in this system of equation. Moreover, the value of $\log$ likelihood function of 902.6691 for the VAR model is relatively large, and AIC value of -17.3184 is small, which indicates that the explanatory ability of the model is very strong. 


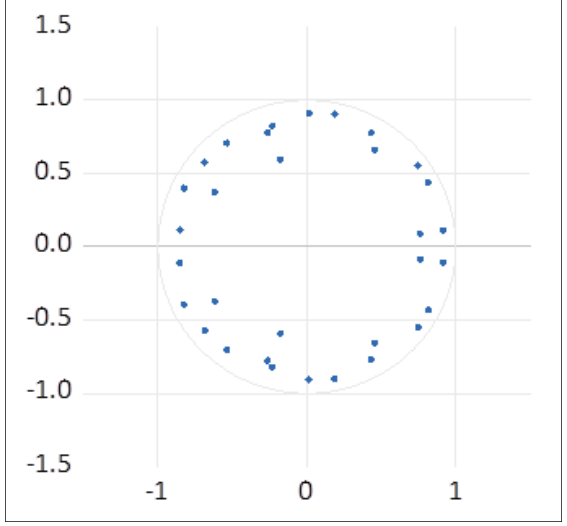

Figure 2: Inverse Roots

Table 4: Vector Autoregression Estimates

\begin{tabular}{|c|c|c|c|}
\hline & \multicolumn{3}{|c|}{ Dependent Variable } \\
\hline & D(LOG(PSEI)) & D(LOG(PHUSD)) & D(LOG(DIESEL)) \\
\hline $\mathrm{D}(\mathrm{LOG}(\mathrm{COVID}(-1)))$ & $\begin{array}{c}0.0101 \\
(0.0162) \\
{[0.6236]}\end{array}$ & $\begin{array}{c}-0.0017 \\
(0.0018) \\
{[-0.9743]}\end{array}$ & $\begin{array}{c}0.0053 \\
(0.0166) \\
{[0.3210]}\end{array}$ \\
\hline $\mathrm{D}(\mathrm{LOG}(\mathrm{COVID}(-2)))$ & $\begin{array}{c}-0.0363^{* *} \\
(0.0170) \\
{[-2.1425]}\end{array}$ & $\begin{array}{c}-0.0013 \\
(0.0019) \\
{[-0.7089]}\end{array}$ & $\begin{array}{c}0.0085 \\
(0.0174) \\
{[0.4862]}\end{array}$ \\
\hline $\mathrm{D}(\operatorname{LOG}(\mathrm{COVID}(-3)))$ & $\begin{array}{l}0.0583^{\star *} \\
(0.0180) \\
{[3.2479]}\end{array}$ & $\begin{array}{c}0.0006 \\
(0.0020) \\
{[0.3162]}\end{array}$ & $\begin{array}{c}0.0175 \\
(0.0185) \\
{[0.9458]}\end{array}$ \\
\hline $\mathrm{D}(\mathrm{LOG}(\mathrm{COVID}(-4)))$ & $\begin{array}{c}-0.0394^{* *} \\
(0.0179) \\
{[-2.2025]}\end{array}$ & $\begin{array}{l}0.0040^{* *} \\
(0.0020) \\
{[2.0156]}\end{array}$ & $\begin{array}{c}0.0000 \\
(0.0184) \\
{[-0.0007]}\end{array}$ \\
\hline $\mathrm{D}(\mathrm{LOG}(\mathrm{COVID}(-5)))$ & $\begin{array}{c}-0.0639 * * \\
(0.0176) \\
{[-3.6382]}\end{array}$ & $\begin{array}{c}0.0021 \\
(0.0019) \\
{[1.0702]} \\
\end{array}$ & $\begin{array}{c}-0.0433^{* *} \\
(0.0181) \\
{[-2.3969]}\end{array}$ \\
\hline $\mathrm{D}(\mathrm{LOG}(\mathrm{COVID}(-6)))$ & $\begin{array}{l}0.0539 * * \\
(0.0188) \\
{[2.8679]}\end{array}$ & $\begin{array}{c}-0.0015 \\
(0.0021) \\
{[-0.7166]}\end{array}$ & $\begin{array}{c}-0.0126 \\
(0.0193) \\
{[-0.6522]}\end{array}$ \\
\hline $\mathrm{D}(\operatorname{LOG}(\mathrm{COVID}(-7)))$ & $\begin{array}{c}-0.0288 \\
(0.0201) \\
{[-1.4340]}\end{array}$ & $\begin{array}{c}-0.0020 \\
(0.0022) \\
{[-0.9064]}\end{array}$ & $\begin{array}{c}0.0136 \\
(0.0206) \\
{[0.6611]} \\
\end{array}$ \\
\hline $\mathrm{D}(\mathrm{LOG}(\mathrm{COVID}(-8)))$ & $\begin{array}{l}0.0638^{\star *} \\
(0.0179) \\
{[3.5618]}\end{array}$ & $\begin{array}{c}-0.0021 \\
(0.0020) \\
{[-1.0842]}\end{array}$ & $\begin{array}{c}-0.0041 \\
(0.0184) \\
{[-0.2202]}\end{array}$ \\
\hline C & $\begin{array}{c}-0.0021 \\
(0.0037) \\
{[-0.5562]}\end{array}$ & $\begin{array}{c}-0.0002 \\
(0.0004) \\
{[-0.4710]}\end{array}$ & $\begin{array}{c}0.0032 \\
(0.0038) \\
{[0.8290]}\end{array}$ \\
\hline $\begin{array}{l}\text { Log likelihood } \\
\text { Akaike information criterion }\end{array}$ & & $\begin{array}{l}902.6691 \\
-17.3184\end{array}$ & \\
\hline
\end{tabular}




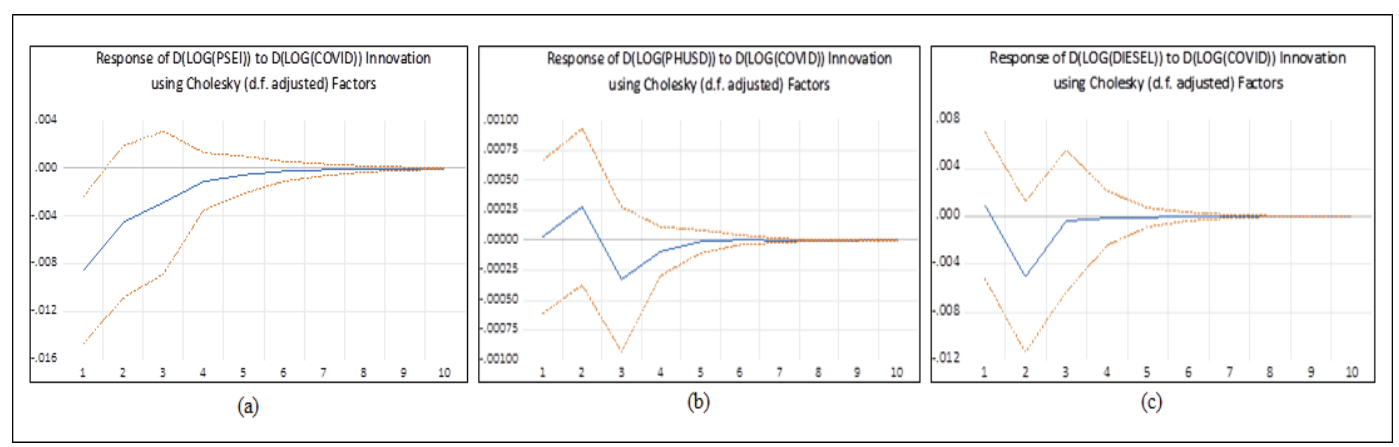

Figure 3: Response to Cholesky One S.D. (d.f. adjusted) Innovations

Table 5: Variance Decomposition

\begin{tabular}{|l|c|c|c|c|c|c|}
\hline \multirow{2}{*}{ Day } & \multicolumn{2}{|c|}{$\begin{array}{c}\text { Variance Decomposition of } \\
\text { D(LOG(PSEI)): }\end{array}$} & \multicolumn{2}{c|}{$\begin{array}{c}\text { Variance Decomposition of } \\
\text { D(LOG(PHUSD)): }\end{array}$} & \multicolumn{2}{c|}{$\begin{array}{c}\text { Variance Decomposition of } \\
\text { D(LOG(DIESEL)): }\end{array}$} \\
\cline { 2 - 7 } & S.E. & D(LOG(COVID)) & S.E. & D(LOG(COVID)) & S.E. & D(LOG(COVID)) \\
\hline 1 & 0.0305 & 8.5547 & 0.0031 & 0.0040 & 0.0301 & 0.0493 \\
\hline 2 & 0.0312 & 9.7517 & 0.0032 & 1.0220 & 0.0304 & 2.1429 \\
\hline 3 & 0.0317 & 10.5813 & 0.0032 & 2.1748 & 0.0310 & 2.0839 \\
\hline 4 & 0.0318 & 10.6107 & 0.0032 & 2.2592 & 0.0310 & 2.1866 \\
\hline 5 & 0.0318 & 10.6205 & 0.0032 & 2.2649 & 0.0310 & 2.1976 \\
\hline 6 & 0.0318 & 10.6194 & 0.0032 & 2.2649 & 0.0310 & 2.1974 \\
\hline 7 & 0.0318 & 10.6216 & 0.0032 & 2.2664 & 0.0310 & 2.1977 \\
\hline 9 & 0.0318 & 10.6215 & 0.0032 & 2.2665 & 0.0310 & 2.1977 \\
\hline 10 & 0.0318 & 10.6216 & 0.0032 & 2.2666 & 0.0310 & 2.1977 \\
\hline
\end{tabular}

Cholesky Ordering: D(LOG(COVID)) D(LOG(PSEI)) D(LOG(PHUSD)) D(LOG(DIESEL))

Figure 3 shows the results of impulse response function under VAR. The blue line is the impulse response function line while the red lines are simply the 95 percent coefficient intervals. The impulse response function always lies within 95 percent coefficient interval. We can observe the response or the reaction of PSEI, PHUSD and DIESEL to the number of COVID-19 daily infections. Figure 3(a) is the impulse response function of the Philippine stock exchange index caused by COVID-19 daily infections shock. As shown in the figure, after a positive shock, the Philippine stock exchange index tends to increase gradually and moves towards positive from negative and becomes steady at zero. Figure 3(b) is the impulse response function of the Philippine peso-US dollar exchange rate to the number of COVID-19 daily infections. A one standard deviation shock or innovation of COVID-19 daily infections to the Philippine peso-US dollar exchange rate initially has noticeable impact, it increases from 1 to 2 days and then gradually decreases being in the negative zone and then becomes stable. Thus, shocks to COVID-19 daily infections will have impact on the Philippine peso-US dollar exchange in the short run. Figure 3(c) demonstrated sharp decline from positive to negative, and then gradually tends towards increment and becomes stable. It can be noticed that the number of COVID-19 daily infections has relatively affected retail pump price of diesel in the short term, and the effects lasts for 4 days.

Generally speaking, the number of COVID-19 daily infections has relatively affected the Philippine stock exchange index, the Philippine peso-US dollar exchange rate and retail pump price of diesel in the short term, but the effects are gentle in the long term.

In Table 5, we can see the results of variance decomposition under VAR environment. Accordingly, in the short run (i.e., $3^{\text {rd }}$ day) shock to the number of COVID-19 daily infections accounts for 10.5813 percent, 2.1748 percent and 2.0839 percent variation of the fluctuations in the Philippine stock exchange index, peso-dollar exchange rate and retail pump price of diesel, respectively. In the long run (i.e., $10^{\text {th }}$ day), variance 
decomposition basically maintains stability at 10.6216 percent for the Philippine stock exchange index, 2.2666 percent for peso-dollar exchange rate and 2.1977 percent for retail pump price of diesel. The magnitude of the contribution of the number of COVID-19 daily infections does not change in the long run (i.e., $10^{\text {th }}$ day). This means that the number of COVID-19 daily infections accounted for an insignificant portion of PSEI, PHUSD and DIESEL fluctuations.

It can be seen from Figure 4 that, in the short term, the number COVID-19 daily infections has influenced the Philippine stock exchange index, the Philippine peso-US dollar exchange and retail pump price of diesel. In the long term, the influence is leveling off.

Table 6 demonstrates the results of VAR Granger causality test using block exogeneity Wald test. We observed that, when the Philippine stock exchange index is the dependent variable, the null hypothesis is rejected at 1 percent significance level. Also, when the dependent variable is the peso-dollar exchange rate, the null hypothesis is rejected at 10 percent level of significance. Therefore, it can be inferred that in the case of the Philippines, the number of COVID-19 daily infections causes changes in the stock exchange index and peso-dollar exchange rate. That is, there is short-run causality running from COVID-19 daily infections to the Philippine stock exchange index (COVID $\rightarrow \quad$ PSEI) and peso-dollar exchange rate (COVID $\rightarrow$ PHUSD). However, COVID-19 daily infections have no causal link with retail pump price of diesel in the short-run. That is, decreasing prices of diesel for the period January 31-June 30, 2020, could be attributed more to supply side shocks (Arezki \& Nguyen, 2020).

\section{Conclusions}

This research strived to examine the effect of COVID-19 pandemic on the Philippine stock exchange, peso-dollar exchange rate and retail pump rice of diesel using robust least squares regression and vector autoregression (VAR) approach. The paper established the correlation patterns suggesting strong negative association, that is, increasing number of COVID-19 daily infections will lead to decreases in the Philippine stock exchange index, retail pump price of diesel and appreciation of the Philippine peso against the US dollar. The robust least squares regression using MMestimation method indicate that the number of COVID-19 daily infections has significant but minimal effect on the Philippine stock exchange index, peso-dollar exchange rate and retail pump price of diesel. Based on the VAR model, the lag values of the independent variable are significant in explaining fluctuations in PSEI, PHUSD and DIESEL. A positive shock to COVID-19 daily infections has affected the Philippine stock exchange index, the Philippine pesoUS dollar exchange rate and retail pump price of diesel in the short term, but the effects becomes negligible in the long term. Simply, the shock of the number of COVID-19 daily infections differ in the short run and in the long run to influence the fluctuations of the impulse receiver (or dependent variables). We also discovered strong evidence of causation running from COVID-19 daily infections to Philippine stock exchange index and from COVID-19 daily infections to peso-dollar exchange rate, not the other way around.

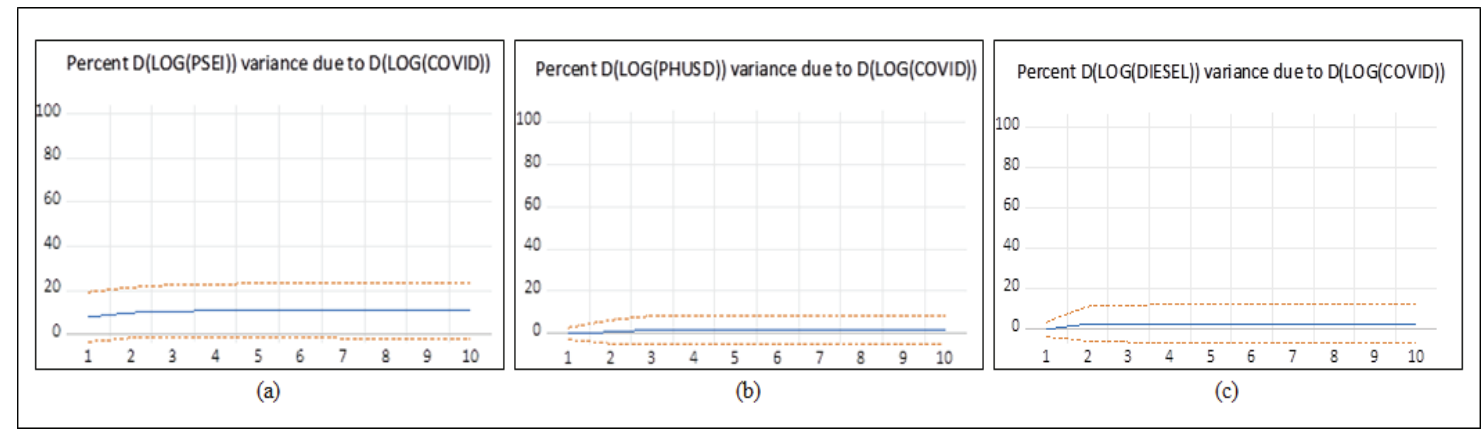

Figure 4: Variance Decomposition Using Cholesky (d.f. adjusted) Factors \pm 2 S.E.

Table 6: VAR Granger Causality (Block Exogeneity Wald Test)

\begin{tabular}{|l|c|c|c|c|}
\hline Null hypothesis & Chi-sq & df & Prob. & Decision \\
\hline D(LOG(COVID)) does not Granger cause D(LOG(PSEI)) & 39.9698 & 8 & 0.0000 & Reject \\
\hline D(LOG(COVID)) does not Granger cause D(LOG(PHUSD)) & 13.4144 & 8 & 0.0984 & Reject \\
\hline D(LOG(COVID)) does not Granger cause D(LOG(DIESEL)) & 11.5831 & 8 & 0.1708 & Accept \\
\hline
\end{tabular}




\section{References}

Alam, M., Alam, S., \& Chavali, K. (2020). Stock Market Response during COVID-19 Lockdown Period in India: An Event Study. Journal of Asian Finance, Economics and Business, 7(7), 131137. https://doi.org/10.13106/jafeb.2020.vol7.no7.131

Araz, O. M., Choi, T. M., Olson, D. \& Salman, F. S. (2020). Data analytics for operational risk management. Decision Sciences. https://doi.org/10.1111/deci.12443

Arezki, R., \& Nguyen, H. (2020). Coping with a dual shock: COVID-19 and oil prices. Retrieved June 18, 2020, from https:/voxeu.org/article/coping-dual-shock-covid-19-and-oilprices

ASEAN Policy Brief. (April 2020). Economic Impact of COVID-19 Outbreak on ASEAN. Retrieved June 18, 2020, from https:// asean.org/storage/2020/04/ASEAN-Policy-Brief-April-2020 FINAL.pdf

Baker, S. R., Bloom, N., Davis, S., Kost, K., Sammon, M., \& Viratyosin, T. (2020). The Unprecedented Stock-Market Reaction to COVID-19. KelloggInsight. Chicago, IL: Kellogg School of Management, Northwestern University.

Baldwin, R., \& Tomiura, E. (2020). Thinking ahead about the trade impact of COVID-19. London, UK: CEPR Press. Retrieved June 18, 2020, from https://voxeu.org/content/economics-timecovid-19

Blanchard, O., Adler, G., \& Filho, I. (2015). Can Foreign Exchange Intervention Stem Exchange Rate Pressures from Global Capital Flow Shocks? IMF Working Paper No. 15/159. Retrieved July 07, 2020, from https://www.imf.org/ /media/Websites/IMF/ imported-full-text-pdf/external/ pubs/ft/wp/ 2015/_wp15159. ashx

Boon, L., Haugh, D., Pain, N., \& Salins, V. (2020). Tackling the fallout from COVID-19. In Economics in the Time of COVID-19. London, UK: CEPR Press. Retrieved July 07, 2020, from https://voxeu.org/content/economics-time-covid-19

Brooks, C. (2019). Introductory Econometrics for Finance. Cambridge, UK: Cambridge University Press. https://doi. org/10.1017/9781108524872

Calnan, M., Gadsby, E. W., Konde, M. K., Diallo, A., \& Rossman, J. S. (2018). The response to and impact of the Ebola epidemic: towards an agenda for interdisciplinary research. International Journal of Health Policy and Management, 7(5), 402. https:// doi.org/10.15171/IJHPM.2017.104

Campbell, J. Y. (1991). A Variance Decomposition for Stock Returns. The Economic Journal, 101(405), 157-179. https:// doi.org/10.2307/2233809

Christiano, L. J. (2012). Christopher A. Sims and Vector Autoregressions. Scandinavian Journal of Economics, 114(4), 1082-1104. https://doi.org/10.1111/j.1467-9442.2012.01737.x

Chou, J., Kuo, N. F., \& Peng, S. L. (2004). Potential impacts of the SARS outbreak on Taiwanese economy. Asian Economic Papers, 3(1), 84-99. https://doi.org/10.1016/j. socscimed.2006.08.004
Collins, C. G., \& Gagnon, J. E. (2020). Exchange rate policy in the COVID-19 pandemic. Retrieved June 18, 2020, from https://www.piie.com/blogs/realtime-economic-issues-watch/ exchange-rate-policy-covid-19-pandemic

Corsetti, G., \& Marin, E. (2020). The dollar and international capital flows in the COVID-19 crisis. Retrieved May 12, 2020, from https://voxeu.org/article/covid-19-crisis-dollar-andcapital-flows

Dickey, D. A., \& Fuller, W. A. (1981). Likelihood ratio statistics for autoregressive time series with a unit root. Econometrica, 49(1), 1057-1072.

Gormsen, N. J., \& Koijen, R. (2020). Coronavirus: Impact on Stock Prices and Growth Expectations. CEPR Policy Portal. Retrieved July 05, 2020, from https://voxeu.org/article/coronavirusimpact-stock-prices-andgrowth-expectations

Granger, C. J. (1969). Investigating Causal Relationships by Econometrics Models and Cross Spectral Methods. Econometrica, 37, 425-435.

Hayat, R., \& Mechelen, R. (2020). How COVID-19 will impact ASEAN: Deep recessions and a weak recovery. Retrieved May 12, 2020, from https://economics.rabobank. com/ publications/2020/may/ impact-covid-19-aseanrecessions-and-weak-recovery/\#342881f1-72da-4673-b002$70938 \mathrm{~b} 035513$

Khan, K., Zhao, H., Zhang, H., Yang, H., Shah, M. H., \& Jahanger, A. (2020). The Impact of COVID-19 Pandemic on Stock Markets: An Empirical Analysis of World Major Stock Indices. Journal of Asian Finance, Economics and Business, 7(7), 463474. https://doi.org/10.13106/jafeb.2020.vol7.no7.463

Lütkepohl, H., \& Krätzig, M. (2004). Applied Time Series Econometrics. Cambridge, UK: Cambridge University Press. https://doi.org/10.1017/CBO9780511606885

Foresti, P. (2006). Testing for Granger causality between stock prices and economic growth. MPRA Paper No. 2962. https:// mpra.ub. uni-muenchen.de/2962/1/MPRA_paper_2962.pdf

Ozili, P., \& Arun, T. (2020). Spillover of COVID-19: Impact on the Global Economy. Retrieved May 11, 2020, from https://doi. org/10.2139/ssrn.3562570

Phillips, P. C., \& Perron, P. (1988). Testing for a unit root in time series regression. Biometrica, 75(1), 335-346. Retrieved June 11, 2020, from http://www.jstor.org/stable/2336182

Ramelli, S., \& Wagner, A. F. (2020). Feverish Stock Price Reactions to the Novel Coronavirus. Retrieved June 11, 2020, from https://doi. org/10.2139/ssrn.3550274

Smith, A. A., Jr. (1993). Estimating Nonlinear Time Series Models Using Simulated Vector Autoregressions. Journal of Applied Econometrics, 8, 63-84. Retrieved June 11, 2020, from https:// www.jstor.org/stable/2285075

Stock, J., \& Watson, M. (2001). Vector Autoregressions. Journal of Economic Perspectives, 15, 101-115. https://doi.org/10.1257/ jep.15.4.101 
The FRED Blog. (2020). Coronavirus effects on exchange rates. Retrieved June 11, 2020, from https://fredblog.stlouisfed. org/2020/04/coronavirus-effects-on-exchange-rates/

Wren-Lewis, S. (2020). The economic effects of a pandemic. In: Economics in the Time of COVID-19. London, UK: CEPR Press. Retrieved June 11, 2020, from https://voxeu.org/content/ economics-time-covid-19

Yilmazkuday, H. (2020). COVID-19 Effects on the S\&P 500 Index. Retrieved June 11, 2020, from http://dx.doi.org/10.2139/ ssrn. 3555433
Yilmazkuday, H. (2020). Coronavirus Disease 2019 and the Global Economy. Retrieved June 11, 2020, from http://dx.doi. org/10.2139/ssrn.3554381

Yohai, V. J. (1987). High Breakdown-Point and High Efficiency Robust Estimates for Regression. Annals of Statistics, 15(20), 642-656. https://doi.org/10.1214/aos/1176350366

Yuliadi, I. (2020). An Analysis of Money Supply in Indonesia: Vector Autoregressive (VAR) Approach. Journal of Asian Finance, Economics and Business, 7(7), 241-249. https://doi. org/10.13106/jafeb.2020.vol7.no7.241 